\title{
A strategic framework for improving food security in Arab countries
}

\author{
Julian A. Lampietti • Sean Michaels • \\ Nicholas Magnan • Alex F. McCalla • Maurice Saade • \\ Nadim Khouri
}

Received: 3 September 2010 /Accepted: 29 November 2010 /Published online: 10 February 2011

(C) The Author(s) 2010. This article is published with open access at Springerlink.com

\begin{abstract}
In 2007 and the first half of 2008, a sharp rise in agricultural commodity and food prices triggered grave concerns about food security, malnutrition and increased poverty. While the threat of a prolonged food-price shock receded in the second half of 2008, many factors underlying the price volatility are likely to persist, and will require careful management if future food-price shocks are to be avoided. This paper suggests three strategies that, together, could reduce vulnerability to price shocks: (1) strengthen safety nets, improve access to family planning services, and promote education; (2) enhance domestic food production
\end{abstract}

J. A. Lampietti $(\bowtie) \cdot$ S. Michaels

Sustainable Development Department,

Middle East and North Africa Region, World Bank,

1818 H Street, NW,

Washington, DC 20433, USA

e-mail: jlampietti@worldbank.org

N. Magnan

Environment and Production Technology,

International Food Policy Research Institute,

2033 K Street, NW,

Washington, DC, USA

\section{A. F. McCalla}

Department of Agricultural and Resource Economics, University of California, Davis,

1 Shields Avenue,

Davis, CA 95616, USA

\section{Saade}

Food and Agriculture Organization of the United Nations,

Viale delle Terme di Caracalla,

00153 Rome, Italy

\section{N. Khouri}

International Fund for Agricultural Development,

44 Via Paolo di Dono,

00142 Rome, Italy and improve rural livelihoods through increased investment in research and development to increase productivity; and (3) reduce exposure to market volatility through more efficient supply chains and better use of financial instruments to hedge risk. The challenge of food security will require a global response, involving governments, international and regional funding and lending institutions, United Nations agencies, non-governmental organizations, civil society, and the private sector.

Keywords Food prices · Safety nets · Market volatility . Food security . Arab countries

Food price shocks: vulnerability, and underlying factors

Very high agricultural commodity prices in the first 6 months of 2008 raised concerns worldwide about increased poverty and malnutrition. Since June 2008, prices have fallen significantly, as a result of strong production gains in developed countries (FAO 2008a), the world financial crisis, lower oil prices, and a strengthening US dollar. But many of the underlying factors causing high and volatile prices still remain. Structural factors, such as population and income growth. ${ }^{1}$ and biofuel demand, may keep prices high in real terms.

Arab countries are vulnerable to fluctuations in international commodity markets because they are heavily dependent on imported food (Fig. 1). Most import at least 50\% of the food calories they consume (FAO 2008b). This raises concerns about both price and supply. In terms of price,

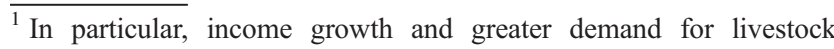
products in China and India have increased global demand for cereal grain.
} 


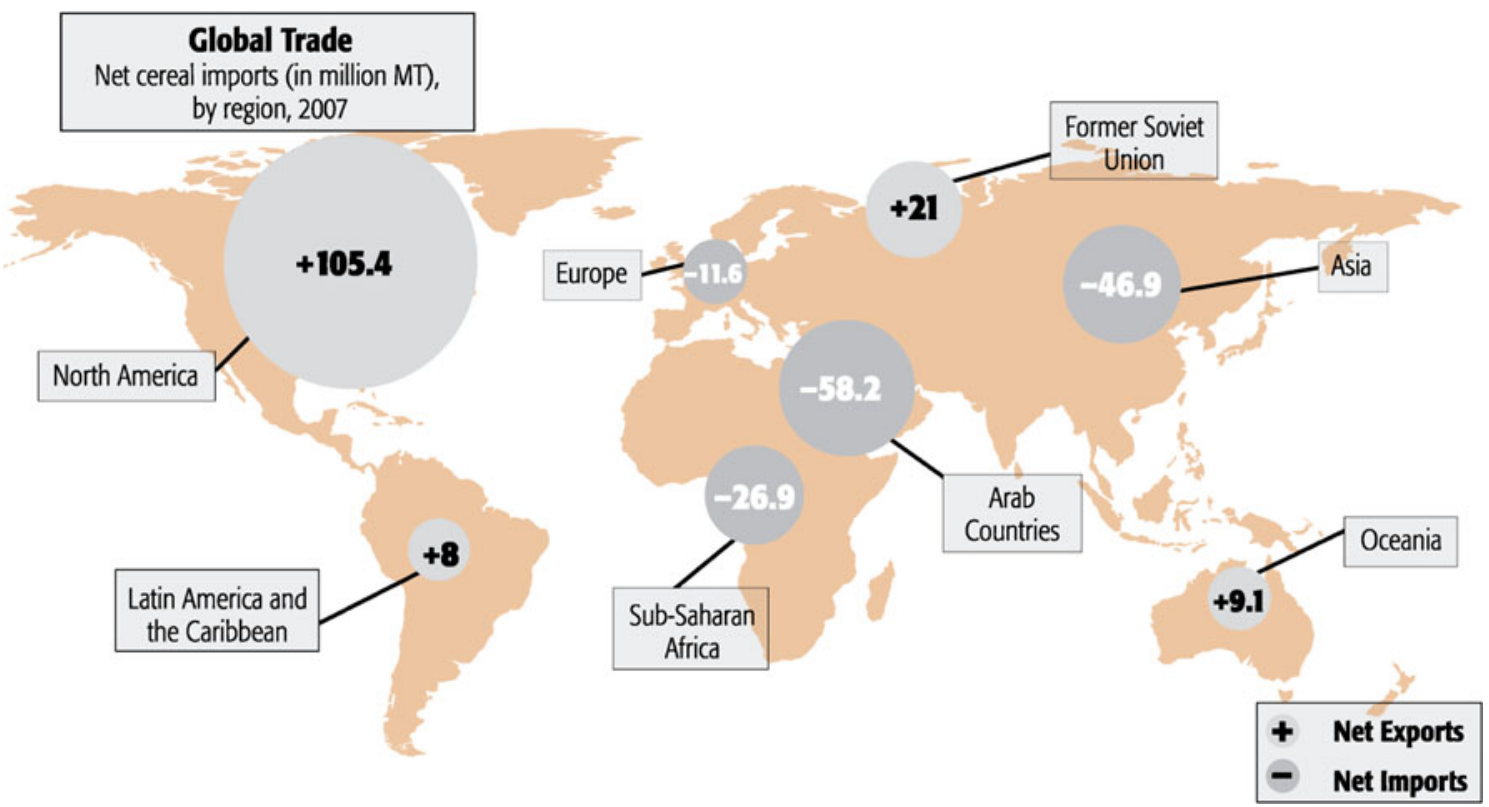

Fig. 1 Arab countries are the largest net importers of cereals (million metric tons, 2007). Source: adapted from FAO (2008e)

high food prices strain household and national budgets. In terms of supply, five exporters (Argentina, Australia, Canada, the European Union, and the United States) supply $73 \%$ of the world's traded cereals (FAO 2008b); supplies are dependent on events in these countries and on Arab countries' relationships with them.

\section{Factors driving food security risks}

The food-price shock of 2008 was caused by the convergence of multiple structural and cyclical factors. ${ }^{2}$ Projections by international agencies (OECD and FAO 2008; World Bank 2008b) suggest a structural shift may prevent prices from returning to pre-crisis levels. While this may or may not be true, of greater concern for Arab countries is that structural and cyclical forces are creating a system that is very sensitive to supply shortfalls, making future price shocks very probable. Food prices can increase surprisingly rapidly; and the impacts are particularly severe because both supply and demand are inelastic. Poor households cannot quickly alter or reduce food consumption in response to high prices. Neither can producers quickly ramp up production in response to high prices, due to the seasonal production cycle and the slow development of new technologies.

Global productivity growth rates for major cereals are slowing (Fig. 2). This is partly because public support for

\footnotetext{
${ }^{2}$ Structural: long-term factors that cause a permanent shift in demand or supply. Cyclical: short-term factors that induce a temporary shift in supply or demand.
}

agricultural research has decreased since 1990 (Ruttan 2002). Unless this trend is reversed, the likelihood of foodprice shocks will increase.

International cereal markets are thin; therefore relatively small shifts in supply or demand can cause large shifts in prices. Only $18 \%$ of world wheat production and $6 \%$ of world rice production is exported; the rest is consumed domestically (FAO 2008d). In 2008, some major exporters banned rice and wheat exports for fear of domestic shortages. These bans contributed to the rapid price increases. The thinner the market, the sharper the fluctuation in prices and the higher the likelihood of future price shocks.

Low stock levels increase price sensitivity to disturbances in demand and supply. Policy reform in recent years, such as replacing price supports with direct farmer payments, has brought down stocks in Organisation for Cooperation and Development (OECD) countries from the high levels of the 1980s and 1990s (Gardner and Sumner 2007; World Bank 2008a). Low stock levels, combined with thin cereal markets and ever-increasing demand, contribute to a just-in-time commodity market that is more vulnerable to disruptions. The United Nations Food and Agricultural Organization (FAO) forecasts global end-ofseason cereal stocks in 2008/09 at 474 million metric tonnes, the highest since 2002/03 (FAO 2008a). As a result, the cereal stock-to-use ratio is forecasted to rise slightly to $22 \%$ - but even so, the probability of price shocks remains high when stocks dip below the $25-30 \%$ range.

Climate change will contribute to market thinness and instability by increasing cereal yield volatility and possibly reducing global cereal production. Climate change models project an increasing probability of droughts and floods 
Fig. 2 Global growth rates of yields of major cereals are slowing: percentage change in growth of yields, 1980-2005. Source: FAO (2008b). Note: Yield growth rates reported as seven-year moving averages

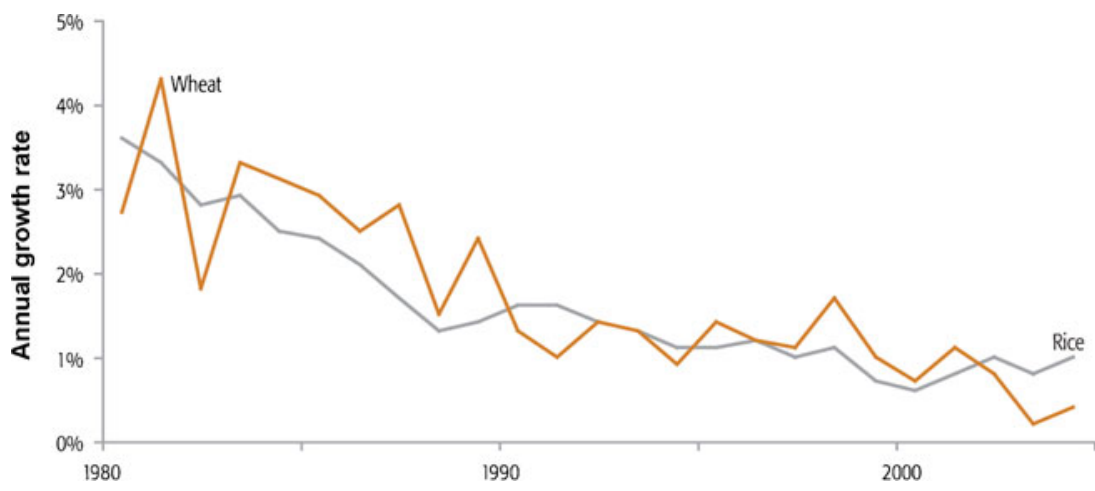

worldwide (Cline 2007). A critical concern for Arab countries is how often droughts and floods occur in key cereal exporting regions. Research on the impact of global warming on cereal production is not conclusive, but average production is likely to decrease. Rosenzweig and Parry (1996) estimate that global cereal production could decrease by $5 \%$ from 1996 to 2060 , even with moderate investment in climate change adaptation.

Policies that promote biofuels such as ethanol and biodiesel, coupled with high domestic tariffs that discourage biofuel imports, shift land away from food production and pasture (FAO 2008e). There is evidence that this is occurring in the United States, which accounts for $28 \%$ of world cereal exports (Fig. 3). Fabiosa et al. (2008) suggest that such policies in the USA will probably transmit directly to higher world-market prices for wheat and oilseeds. Sustaining such policies in the future would contribute to thinner wheat markets and an upward structural adjustment in wheat prices. Similar biofuel policies in the European Union, Canada, and elsewhere could affect the production of wheat, coarse grains, oilseeds, sugar, and other crops.

Petroleum is the primary ingredient of two key agricultural inputs, diesel and fertilizer. The cost of transporting food also depends on the price of fuel. A recent study indicates that when oil prices are above US\$50 a barrel, oil and food commodity prices move together, but when the oil price falls below US\$50, oil and food prices decouple (World Bank 2009). If oil price shocks occur concurrently with food price shocks, as they did in summer 2007, oil producers will be partly insulated, while non oil-producers will not.

This is not to say that oil-producing counties should not be concerned with high food prices. Even when oil prices are high, these countries typically have many competing uses for oil revenues, and high food import costs reduce governments' ability to meet investment objectives. Rising petroleum prices can also impact commodity prices by increasing the demand for biofuels, which diverts cereals and sugar from food to fuel (FAO 2008c).

Monetary policies, currency fluctuation, and financial speculation may have also contributed to the 2008 shock.
Low interest rates reduce the price of storage and encourage the buying and holding of commodities (Frankel 2008). The recent decline of the US dollar against other hard currencies increased the demand for these goods, since commodities priced in dollars became cheaper in real terms. Financial speculation may also have played a role. In times of uncertainty and/or recession, investors shift to physical assets including commodities. This leads to large increases in non-traditional investments in commodity markets as fund investors bet on continued price increases. However, recent research (Carter et al. 2008) suggests that speculation may be a symptom, not a cause, of the food-price shock.

\section{Will food-price shocks continue to be a problem?}

Population growth, urbanization, and income growth are relatively strong in Arab countries and will increase the demand for food. Supply-side constraints are also more binding in most Arab countries than elsewhere because of scarcity of water and arable land. Thin cereal markets and climate change will increase price sensitivity to disturbances in these demand and supply factors. The potential decoupling of petroleum and food commodity prices may affect the fiscal balances of oil-producing countries, reducing their ability to cope with future shocks. It is not known if world food prices will be high or low, but it is certain that Arab countries will remain vulnerable to food price and quantity shocks.

Food demand is increasing faster in Arab countries than worldwide, largely due to structural factors. Population growth rate in the Arab countries is projected to be $1.7 \%$, compared to $1.1 \%$ globally (World Bank 2008b). ${ }^{3}$ Income growth, at $3-3.4 \%$, is also faster than the global average (World Bank 2008b). ${ }^{4}$ Urbanization is also increasing: urban population in Arab countries grew by 3\% during the

\footnotetext{
${ }^{3}$ Population data are for the World Bank's Middle East and North Africa region (MENA).

${ }^{4}$ Income as measured by annual percentage change in GDP per capita PPP at constant 2005 international dollars from 2001-2007.
} 
Fig. 3 Biofuel policies in the USA may contribute to substitution of wheat with maize (1980-2017 area planted, million hectares). Source: USDA (2008b)

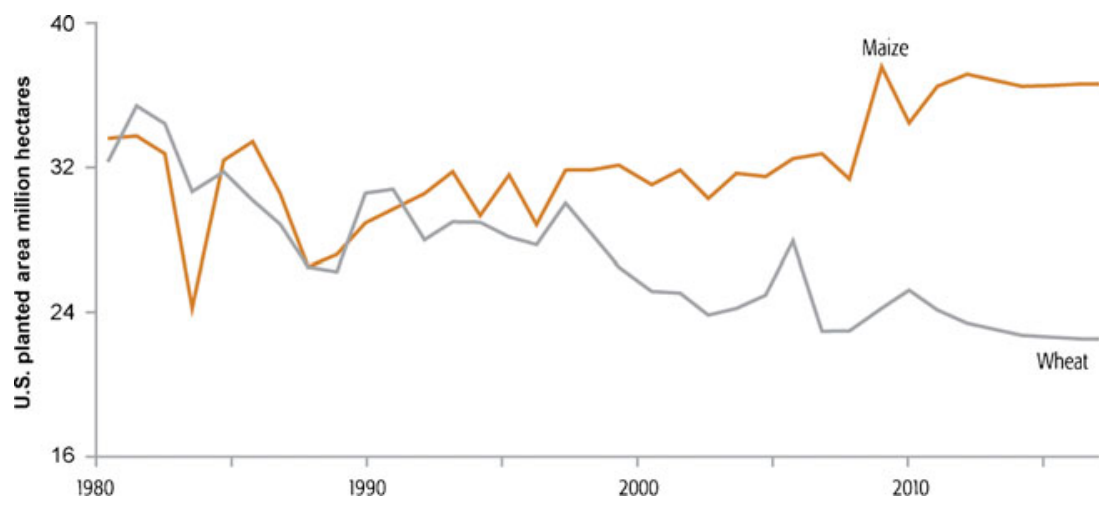

1990-2006 period, compared to the global average of $2.2 \%$ (FAO 2008b).

Water and land constraints are particularly challenging. Approximately $75 \%$ of exploitable renewable water resources in Arab countries are taken out of the natural system and used, compared to between $1 \%$ and $30 \%$ in other regions (World Bank 2007a). In some areas, non-renewable sources such as fossil groundwater are being exploited. Consequently, there is little or no potential for sustainable increase in water use in most Arab countries. Expansion of arable land is similarly limited. The annual growth rate of arable and permanent cropland during 1995-2005 was $1.7 \%$ in Arab countries excluding Sudan, 6.7\% including Sudan, and 2.3\% worldwide (FAO 2008b). In addition, cereal yields have grown relatively slowly: from 1990 to 2007 , average cereal yields increased by $14.5 \%$ in the Arab region, compared to $21.5 \%$ worldwide.

\section{The impact of price shocks on Arab economies}

There are important lessons about the potential macro and microeconomic effects of high food prices, and the results of government responses. At the macro level, inflation in Arab countries has increased more than twice as fast as world inflation in recent years (IMF 2008). High energy and food prices are driving factors, outpacing overall inflation by several percentage points. High food prices also deteriorate trade balances. Most Arab countries provide subsidies in response to high food prices, but this can strain fiscal balances (Fig. 4). Although food commodity prices have fallen subsequently, they remain higher than pre-crisis levels, and inflation remains a concern. The global financial crisis and declining oil prices will significantly reduce the fiscal balances of the wealthier oil-exporting Arab countries, and their ability to absorb food-price shocks. At the micro level, the price shock probably made poverty both more widespread and more severe, although it is too early to determine the exact damage. The poor are the most vulnerable, because they spend the largest share of their budget on food. Foodprice shocks can push people above the poverty line into poverty, and worsen the condition of those who are already poor.

\section{The impact of price shocks on government budgets}

Non-oil-exporting countries face increasing fiscal pressure due to the price shock. In addition to inflation, food-price shocks directly affect trade and fiscal balances. Many Arab countries (e.g., Egypt, Jordan, Syria, and Yemen) have increased public sector salaries and have tried to support the poor by increasing bread subsidies, implementing direct cash transfers, and lifting tariffs on basic food commodities. However, these measures are not sustainable without concurrent increases in revenues. To finance the additional expenditures, oil-poor countries may be forced to reduce other essential expenditures or increase borrowing, which could
Fig. 4 Oil-poor countries have fiscal deficits, while oil-rich countries have surpluses (2007 balances). Source: World Bank (2008b). * Syria, Yemen and Egypt are oil exporters, but their production and net exports are small compared to the oil-rich countries

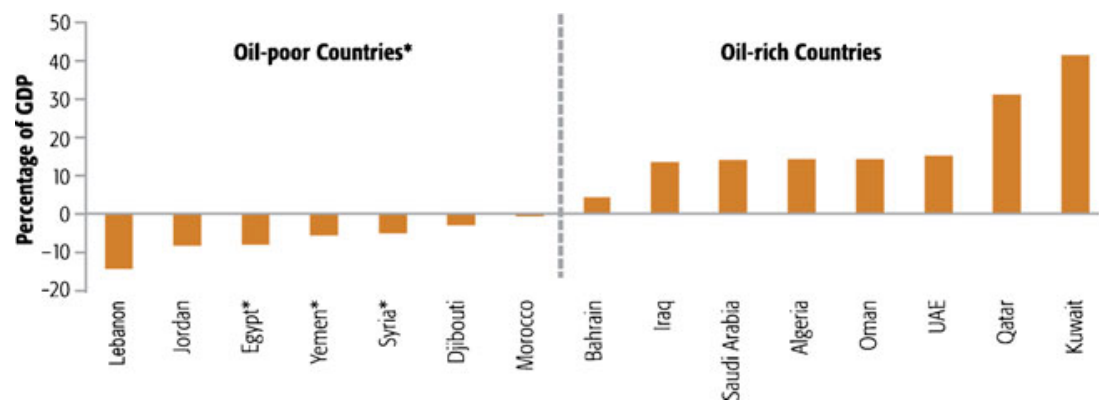


Fig. 5 Food subsidies are a high share of GDP in some countries (2007). Source: World Bank (2008b)

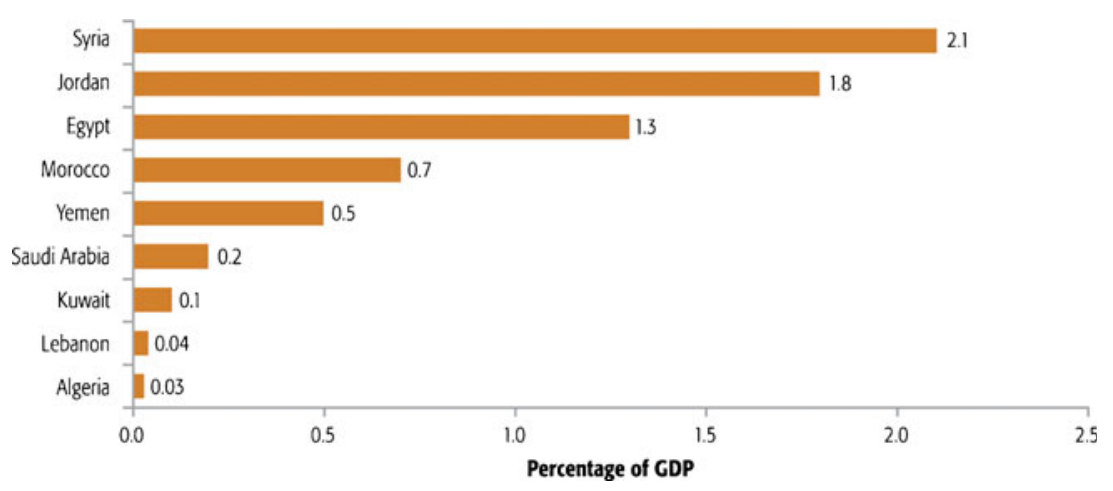

damage economies in the long term. Non-oil-exporters that rely significantly on cereal imports (Jordan, Lebanon, Morocco, and Djibouti) all have fiscal and trade deficits, contributing to economic hardship. However, rising revenues from other commodity exports have eased some of the burden in oil-poor countries that are rich in other natural resources. For example, Morocco's phosphate exports tripled in value in 2008 and covered the oil deficit, while Jordan's export of potash helped cushion its food-import bills.

Oil-rich countries have been able to maintain fiscal surpluses, raise public sector wages and implement large food subsidy programs despite high food prices. However, the recent decline in oil prices may reduce trade surpluses, foreign exchange earnings, government revenues, and investment options in these countries. If oil prices continue to decline but food prices remain high, fiscal and trade surpluses could become chronic deficits.

Across-the-board food subsidy programs can create a substantial fiscal burden. Food-price shocks drive up the cost of government food subsidies. But a common government response to shocks is to increase the coverage and size of these subsidies, driving up costs even further. In countries such as Syria and Egypt, which have across-the-board subsidies, the subsidies exceed $1 \%$ of GDP and could become a major fiscal problem if commodity prices stay high, or in the event of future price shocks (Fig. 5). ${ }^{5}$ While social and political considerations may make it hard to rationalize food subsidies, this paper outlines potential strategies to improve performance and reduce the fiscal burden.

\section{The impact of price shocks on poverty}

Rural poverty is at the core of Arab countries' food-security problems. About one quarter of the population of Arab countries is poor, and $76 \%$ of these live in rural areas. Poverty rates in rural areas are also dropping more slowly

\footnotetext{
${ }^{5}$ This pales in comparison to energy subsidies, which average $7 \%$ of GDP across the region (World Bank 2008j).
}

than in urban areas (IFAD and FAO 2007). Table 1 shows rural and urban poverty rates in countries for which data are available. Clearly, there is a need for social safety nets designed to reach the poor; this is discussed later.

Higher food prices contribute to the incidence, depth, and severity of poverty. The poor are hit hardest by foodprice shocks, because they spend between $35 \%$ and $65 \%$ of their income on food. Rough calculations suggest that, barring economic growth, a $30 \%$ increase in food prices in Egypt would have resulted in a 12 percentage point increase in poverty. In Morocco, a $14 \%$ increase in food prices would have resulted in a 4 percentage point increase in poverty. In Djibouti a $21 \%$ increase in the food consumer price index (CPI) could have pushed extreme poverty up by 14 percentage points. ${ }^{6}$ These are severe impacts, reflecting a characteristic feature of the region: with a relatively high concentration of people living near the poverty line, poverty numbers are very sensitive to even small increases in the cost of living (World Bank 2006).

Higher food prices will affect some groups more than others. The worst affected will be the urban poor, the rural landless, and small and marginal farmers. Large farmers will be partially buffered since they are likely to benefit from higher produce prices (FAO 2008f). In contrast, a large proportion of small farmers in several Arab countries stand to lose from higher food prices because they are net consumers of food. Preliminary findings from Yemen are alarming. Between 2006 and 2008 the percentage of undernourished people in the surveyed population rose from $24 \%$ to $59 \%$ (World Food Program 2008). In order to help marginal groups become food secure, employment opportunities must be generated. Strategies to create economic activity in rural areas are dealt with in a separate section.

\footnotetext{
${ }^{6}$ These figures are from simulations and represent maximum possible effects. They refer to the changes in food prices (or food component of the CPI) during the period pre-crisis (2005) to early 2008, assuming no income growth and no substitution away from food. They do not take into account possible benefits of higher food prices on farmers' incomes.
} 
Table 1 The poor are concentrated in rural areas (various years)

\footnotetext{
${ }^{a}$ World Bank (2008d)

${ }^{\mathrm{b}}$ IFAD and FAO (2007)

${ }^{\mathrm{c}}$ World Bank (2008b)

Poverty as determined by national poverty line
}

\begin{tabular}{lccc}
\hline Country & \% of urban who are poor & \% of rural who are poor & \% of poor in rural areas \\
\hline Yemen $^{\mathrm{a}}$ & 21 & 40 & 84 \\
Djibouti $^{\mathrm{a}}$ & 39 & 83 & 31 \\
Egypt $^{\mathrm{a}}$ & 10 & 27 & 78 \\
Sudan $^{\mathrm{b}}$ & 27 & 85 & 81 \\
West Bank and Gaza $^{\mathrm{a}}$ & 21 & 55 & 67 \\
Jordan $^{\mathrm{a}}$ & 12 & 19 & 29 \\
Syria $^{\text {Algeria }}$ & 8 & 15 & 62 \\
Mauritania $^{\mathrm{c}}$ & 10 & 15 & 52 \\
Morocco $^{\mathrm{a}}$ & 30 & 50 & 78 \\
Tunisia $^{\mathrm{a}}$ & 5 & 15 & 69 \\
\end{tabular}

Smallholder farmers usually form the majority of the rural population and the rural poor. Enabling smallholders to become more productive improves household food security, and in turn national food security. Therefore, successful smallholder farming should also be recognized as a food security goal (IFAD and FAO 2007; FAO 2008f). The need to invest in smallholder agriculture will be discussed further.

For some groups, the impact of the food-price shock may endure even after prices drop. Households in extreme poverty may sacrifice productive inputs to purchase food, reducing their earning potential in the following year. For example, in Yemen $10 \%$ of surveyed farmers consumed their seed stocks for food (World Food Program 2008). Some poor households are undoubtedly forgoing health and education expenditures in order to feed themselves, sacrificing the productivity of future generations. The same study in Yemen showed that $39 \%$ of surveyed households reduced their expenditures on health (World Food Program 2008).

\section{Food security, resource endowments, and fiscal balances}

Exposure to food price and quantity risk is a function of fiscal balances and dependence on cereal imports. Arab countries are price takers and import dependent, and are thus exposed to substantial price and quantity risk. Price risk is the risk that prices will be prohibitively high, making purchase difficult even though supplies are available on world markets. Quantity risk is the risk of food not being available, even if there are sufficient funds for purchase. Figure 6 illustrates the relationship between import dependence, fiscal balance, and risk. Import-dependent countries with strong fiscal balances (e.g., the Gulf Cooperation Council (GCC) countries) are less vulnerable to price risk, but are concerned about quantity risk stemming from export bans and other trade restrictions.

GCC countries are most vulnerable to food-price shocks when oil prices are low and food commodity prices are high. Depletion of oil reserves will reduce their ability to cushion the impact of future food-price shocks. Cyclical factors such as falling demand for oil are contributing to the recent decline in oil prices, reducing oil exporters' incomes. Structural factors driven by Western concerns about energy security and global warming may contribute to a longerterm slump in oil prices. These factors could decouple oil and food commodity prices, making it more difficult for oilrich countries to offset terms of trade losses, which occur when a country's balance of trade deteriorates. ${ }^{7}$

Djibouti, Yemen, Morocco, Jordan, Tunisia, and Lebanon are most vulnerable because they face both high quantity and high price risk. ${ }^{8}$ Price risk is a problem because weak fiscal balances constrain government financing options. Quantity risk is a problem because of high dependence on imports. These countries may need external support to address food security challenges because they lack the fiscal resources to handle shocks.

Sudan, Egypt, and Syria face low quantity risk (less dependent on imports) but high price risk (weak fiscal balances). While these countries are less dependent on imports, they have food-subsidy programs that weaken their fiscal balances. The following section presents strategies to make these programs cheaper and more effective.

No Arab country is protected from future food-price shocks. Each country needs to assess how much price and quantity risk it can tolerate, and how much it can afford to mitigate, and thus devise a strategy to minimize the impact

\footnotetext{
${ }^{7}$ This is a long-term risk since fossil fuel substitutes remain expensive. Oil-rich countries can reduce their vulnerability by using current oil revenues to diversify their economies to reduce dependence on oil revenues.

${ }^{8}$ In Tunisia, for example, it is estimated that food trade balance fell from 277 million Dinars surplus in 2006 to 427 million deficit in 2007; import coverage went down from $121 \%$ to $79 \%$. The country imported 296,600 t of wheat in January and February 2008, 11.8\% less than in the same period in 2007, but at twice the cost. Disbursements under the Caisse de Compensation were 575 million Dinars in 2007 (1.3\% of GDP) against 321 million Dinars in 2006.
} 
Fig. 6 Arab countries with high cereal import dependence and large fiscal deficits are the most vulnerable at macro level (2007 fiscal balance as percentage of GDP from IMF data, 2005 cereal balance in metric tons from FAOSTAT data). Sources: adapted from FAO (2008b), IMF (2008), World Bank (2008b). Note: cereal import dependency measured by net imports/total consumption

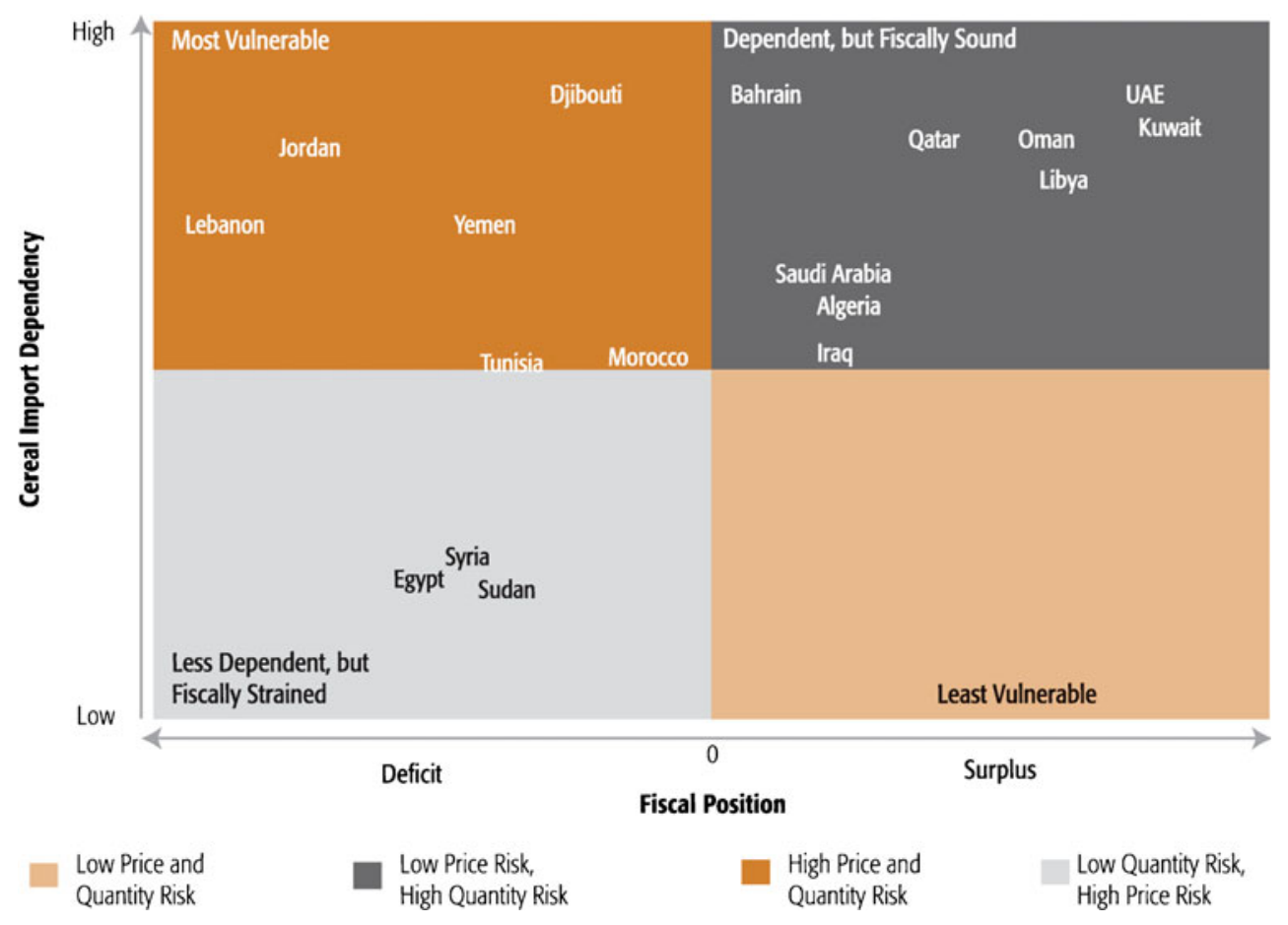

of future price shocks. Such a strategy would address the growth in food demand, increase domestic production, and manage exposure to price volatility. At the same time, countries can reduce fiscal pressure by designing more efficient safety nets.

\section{Components of food security strategies}

Any food security strategy must first address the issue of demand growth. Food-price shocks will be catastrophic for the younger generation if they lead to reduced household investment in health, nutrition, and education. Effective safety nets are crucial. But creating financially sustainable safety nets that assist households in greatest need, requires improved targeting and flexibility, so that safety net programs can be scaled up or down as needed. Other components of a strategy are better access to family planning services, and educating people about health and nutrition.

\section{Current protection measures}

Arab governments responded to the recent price shock with a combination of trade policies, wage increases, and safety-net programs (Table 2). Trade- and tax-policy changes have been a common initial response, aimed at increasing food security and controlling consumer prices. Morocco reduced wheat tariffs substantially and provided subsidies to wheat importers. Egypt banned rice exports. Syria imposed export restrictions and reduced taxes on food grains. Djibouti eliminated consumption taxes on several food staples and is providing limited food assistance to rural families through donor support. Tunisia reduced taxes on wheat and is keeping price controls on strategic staples. Yemen is temporarily providing wheat subsidies, and Jordan is maintaining bread subsidies. ${ }^{9}$ Public-sector wages have been increased in several countries including Jordan, Egypt, Syria, Yemen, Saudi Arabia, and Oman, largely as 'compensation' for higher energy and food prices. Some countries have used cash transfers to increase the purchasing power of the poor. ${ }^{10}$ Egypt recently expanded its small cash-transfer program. Yemen has created a workfare program building on an infrastructure-based social fund and is reforming and expanding its cash-transfer program. Many of these actions will be difficult to remove or scale back. Increasing public-sector wages is a permanent and untargeted response, fueling inflationary pressure. When recipients become accustomed to the benefits of maintaining or, as in the case of Egypt, expanding food subsidies or rations, it can be very difficult to remove them, even if market prices fall. In the wake of the recent global financial crisis, Arab governments are expected to reduce food subsidies further-creating additional challenges.

Many countries in the region (Egypt, Jordan, Syria, Morocco, and others) rely on food subsidies as the primary safety net. In-kind food subsidies are particularly popular and many countries expanded these subsidies in 2008 and

\footnotetext{
$\overline{9}$ Jordan eliminated other food and energy subsidies as part of broader reform.

${ }^{10}$ Cash transfers can be unconditional, given to everyone who qualifies based on predetermined criteria, or conditional, where cash is given in exchange for behavior modification (e.g., sending children to school).
} 
Table 2 Arab countries used various economy-wide policies and existing social protection programs to address the price shock

\begin{tabular}{|c|c|c|c|c|c|c|c|c|}
\hline \multirow[b]{2}{*}{ Country } & \multicolumn{4}{|c|}{ Economy-wide policies } & \multicolumn{4}{|c|}{ Existing social protection programs } \\
\hline & $\begin{array}{l}\text { Reduce taxes } \\
\text { on foodgrains }\end{array}$ & $\begin{array}{l}\text { Increase supply } \\
\text { using foodgrain stocks }\end{array}$ & $\begin{array}{l}\text { Export } \\
\text { restrictions }\end{array}$ & $\begin{array}{l}\text { Price controls/ } \\
\text { Consumer subsidies }\end{array}$ & $\begin{array}{l}\text { Cash } \\
\text { transfer }\end{array}$ & $\begin{array}{l}\text { Food for } \\
\text { work }\end{array}$ & $\begin{array}{l}\text { Food } \\
\text { ration/stamp }\end{array}$ & $\begin{array}{l}\text { School } \\
\text { feeding }\end{array}$ \\
\hline Egypt & & & $\sqrt{ }$ & $\sqrt{ }$ & $\sqrt{ }$ & & $\sqrt{ }$ & \\
\hline Morocco & $\sqrt{ }$ & $\sqrt{ }$ & & $\sqrt{ }$ & & & & $\sqrt{ }$ \\
\hline Tunisia & $\sqrt{ }$ & $\sqrt{ }$ & & $\sqrt{ }$ & $\sqrt{ }$ & & & \\
\hline Yemen & & $\sqrt{ }$ & $\sqrt{ }$ & $\sqrt{ }$ & $\sqrt{ }$ & & & \\
\hline Lebanon & $\sqrt{ }$ & & & $\sqrt{ }$ & & & & $\sqrt{ }$ \\
\hline Syria & $\sqrt{ }$ & $\sqrt{ }$ & & $\sqrt{ }$ & $\sqrt{ }$ & & $\sqrt{ }$ & $\sqrt{ }$ \\
\hline Jordan & $\sqrt{ }$ & & & $\sqrt{ }$ & $\sqrt{ }$ & & & $\sqrt{ }$ \\
\hline West Bank and Gaza & $\sqrt{ }$ & & & & $\sqrt{ }$ & & $\sqrt{ }$ & $\sqrt{ }$ \\
\hline Iraq & $\sqrt{ }$ & $\sqrt{ }$ & $\sqrt{ }$ & $\sqrt{ }$ & $\sqrt{ }$ & & $\sqrt{ }$ & \\
\hline Djibouti & $\sqrt{ }$ & & & $\sqrt{ }$ & & $\sqrt{ }$ & & $\sqrt{ }$ \\
\hline
\end{tabular}

World Bank (2008b)

2009. While energy subsidies constitute by far the largest safety-net component in most countries, food subsidies absorb up to $2 \%$ of GDP in some cases (Fig. 6). ${ }^{11}$ Subsidies have several disadvantages. First, they divert resources from alternative, more productive uses. Second, when they are not targeted, they are unnecessarily expensive, because most benefits are captured by the non-poor. ${ }^{12}$ And third, food distribution systems entail heavy administrative overhead, substantial storage losses, and encourage corruption, waste, and leakage of food to non-human uses.

Existing safety nets do not reach those most in need; they need to be better targeted. Most cash-transfer programs in the region are small, costing less than 1\% of GDP. Most programs target by category: households and individuals are entitled to benefits if they fall into eligible categories, such as single mother, widow, unemployed, elderly, or disabled. These categories are not limited to the poor, and do not necessarily cover the poorest households. For example, Egypt's social-assistance program covers less than $12 \%$ of the poor; in 2008 it was estimated that between $48 \%$ and $60 \%$ of the benefits leaked to the nonpoor (World Bank 2008k). In Yemen in 2005, the Social Welfare Fund cash-transfer program reached only $13 \%$ of the poor. Of those who received transfers, $70 \%$ were not in the target group. The National Aid Fund in Jordan covered less than $20 \%$ of the eligible population in 2005 , and of those who received aid, only $14 \%$ were actually eligible.

\footnotetext{
${ }^{11}$ In 2006-2007, energy subsidies were more than $11 \%$ in Syria and $7 \%$ in Egypt.

${ }^{12}$ Yemtsov (2008) estimates that in Egypt a person in the richest quintile receives three times the subsidies compared to a person in the poorest quintile. In Morocco the poor receive $10 \%$ of what the government spends on universal price subsidies; $90 \%$ goes to subsidized goods consumed by the non-poor.
}

\section{Minimizing the impact of price shocks}

Arab countries can improve the design of safety nets to minimize the impacts of food-price shocks and prevent them from doing permanent harm. Simulations indicate that a sharp drop in poverty headcount, depth, and severity would be possible in many countries if category-based transfers are replaced with transfers targeted through a proxy-means test $^{13}$ coupled with geographic targeting (World Bank 2009). Proxy-means testing is usually effective in identifying the chronic long-term poor. Poverty alleviation can be strengthened by increasing the budget for such programs, rather than generalized subsidies. Most Arab countries have the datasets required for targeting, and many are already adopting or considering this approach.

Cash transfers can protect those most in need, and may be more cost effective than in-kind subsidies. In comparison to in-kind subsidies, cash transfers do not distort commodity markets, typically have lower administrative costs, and allow beneficiaries to choose what to purchase. Payment systems can be designed to limit leakages. Conditional cash transfers ${ }^{14}$ are a viable option. For example, transfers could be made conditional on a child attending school. ${ }^{15}$ Brazil's Bolsa Familia and Mexico's Progresa/Oportunidades are examples of successful largescale conditional cash-transfer programs.

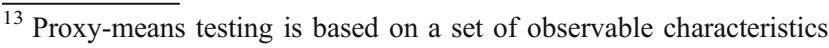
that are correlated with poverty. Beneficiaries are identified based on these characteristics, not through direct income measures.

${ }^{14}$ Cash assistance is provided to poor families conditional on behavior, e.g., keeping children in school or maintaining health regimes.

${ }^{15}$ The World Food Programme's school-feeding programs in Yemen targets girls' schools, and has had a significant impact in improving school attendance (IRIN 2005).
} 
Countries can strengthen such programs in various ways. At the policy level, better coordination can reduce overlapping beneficiaries and mandates. For example, safety nets in the West Bank and Gaza are provided through a number of programs supported by the government, international donors, NGOs, and charitable organizations, some of which have the same target populations. At the program level, payment mechanisms, administrative operations and staffing can be improved. Egypt is piloting an electronic 'smart' card for its ration system that will eventually include cash transfers and other benefits such as health insurance. The smart card can be used to track and distribute benefits through banks. However, implementation may be difficult in rural areas, where card usage is limited by lack of education or infrastructure.

Safety nets must be flexible enough to be scaled up when shocks strike and scaled down when they recede. If possible, existing targeted cash-transfer programs should be the prime candidates to be scaled up. These include poverty-focused social assistance, as well as social pensions, unemployment assistance, and disability pensions. Where public workfare is already part of the safety net, it may be useful to expand program reach. The next most desirable candidate would be food stamps or other nearcash assistance that could be targeted and scaled up or down. Direct subsidies and food distribution would be the least desirable option, advisable only when food markets are functioning poorly or when subsidies are the only available safety net.

Access to family-planning services must be improved. Arab countries have extremely high population growth rates; their combined population rose from 73 million in 1950 to 333 million currently, and is expected to reach nearly 600 million by 2050 . Higher incomes, urbanization, and education can contribute to long-term reductions in birth rates. Access to family planning services has also proven to be highly effective in reducing population growth rates, for example in Algeria, Egypt, Lebanon, Morocco, and Tunisia. Widespread provision of family planning services in Jordan, Mauritania, Yemen, and other countries with high population growth could have multiple long-term benefits, including food security.

Finally, Arab countries can educate families about the benefits of a balanced diet. Diets will improve as incomes increase, but this trend can be accelerated through education programs targeting children and women (the latter play a key role in determining the composition of household diets). A primary objective of such programs would be to make people aware of the nutritional composition of staple foods. For example, $40-45 \%$ of the nutritious value of white flour products, from vitamins to fiber, is lost during bleaching and other processes. Education programs could highlight the benefits of whole wheat flour over white flour.

\section{Optimizing investment to increase productivity and profitability}

Any food-security strategy must aim to increase agricultural productivity. Higher productivity can increase the purchasing power of the rural poor, increase foreign-exchange earnings, and reduce import dependence. Arab countries have little room for expansion of arable land or irrigation, so the emphasis must be on increasing productivity and value per unit of land and water. This will require investment in research, extension, and technology transfer.

\section{The role of productivity}

Productivity gains will remain critical to meeting increasing demand for food. The evidence presented in "Food price shocks: vulnerability, and underlying factors" suggests that there are a number of persistent structural factors that may keep agricultural commodity prices high in the future. However, it may be useful to look at prices over the last 100 years (Fig. 7). Since the early 1900s, real wheat prices in the USA have fallen, due to expansion and technological change. In the 19th and the first half of the 20th century, food output increased primarily due to an expansion of the area planted. In the second half of the 20th century, the increase came mostly from intensification (Evans 1998). Agricultural land continues to expand, but the rate of expansion has slowed. Similarly, decompositions of productivity gains suggest that research and development have been the major drivers of growth since the 1960s. Productivity gains from the Green Revolution eased high food prices after the 1970 oil shock. However, as prices declined through the first half of this decade, so did worldwide investment in agricultural research and development (World Bank 2008e).

\section{Making the most of scarce water resources}

Non-agricultural water demand is growing rapidly. Today approximately $85 \%$ of all abstracted surface water and groundwater in Arab countries is already used for irrigation, and this number must decrease. Although some advances have been made, creating new water for large-scale irrigation using desalination is not yet economically viable for most agricultural activities (Beltrán et al. 2004; Chaibi 2000; Medina 2004; Veza 2004). The use of treated wastewater to irrigate food crops can also be problematic, because it often encounters public resistance, although this is changing (World Bank 2007a, b). Using wastewater to irrigate nonfood crops should still be encouraged, because it frees up water for other uses. Water harvesting (capturing runoff flow after rainfall events) is another viable option. It is important to 
Fig. 7 Historically, wheat prices have fallen. Source: USDA (2008a)

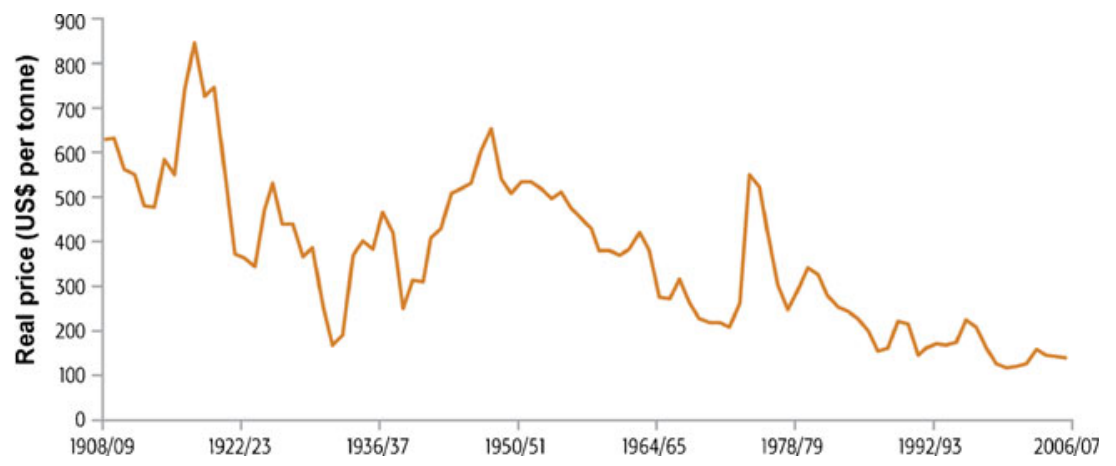

recognize that desalination, wastewater recycling, and water harvesting have their limits. Together they could amount to $20-25 \%$ of abstracted water, but they come at a high cost.

Policies that lower farmers' water costs encourage nonbeneficial and low-value use. Water and energy subsidies that reduce the price of water encourage farmers not to maximize the value of water (World Bank 2007a, b). First, water is lost when flood irrigation is used instead of water-saving irrigation systems like sprinklers and drip. Second, farmers choose crops with low value added per drop of water. For example, vegetable production yields six times more value added per drop of water than wheat production, and ten times more than beef production. When farmers are encouraged to pay the full cost of water, they voluntarily switch their use of irrigated land from low-value crops such as wheat to higher-value crops such as fruits and vegetables. In addition, they have incentives to invest in water-saving irrigation technologies.

Encouraging farmers to replace cereals with high-value crops has mixed implications for food security. ${ }^{16}$ The World Bank's World Development Report (2008e) argues that the top agricultural priority for most Arab countries is to diversify production out of staples and into high-value crops (fruits and vegetables) for export. High-value crop production gives landowners more entrepreneurial opportunities, creates more employment for women and landless workers, and raises agricultural wages. In countries that have a mix of rainfed and irrigated agriculture, such as the Maghreb countries, the Mashreq, and Sudan, water pricing could create a natural split: cereals would be grown primarily under rainfed conditions, and high-value crops under irrigation. This would increase dependence on imported cereals, but would also generate more foreign exchange from high-value crop exports that would cover the cost of additional cereal imports. This would also be more profitable for farmers and leave them disposable income to buy staples. Any effort to convert cereal land to high value crops must also ensure that farmers have access to domestic or export

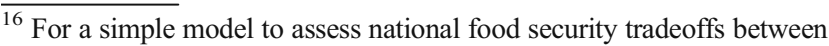
maintaining high levels of cereal self-sufficiency and converting cereal land to high value export crops, see Magnan et al. (2009).
}

markets to sell these crops. This is not to say that countries that depend entirely on irrigation should stop growing cereal where it is economically viable and sustainable, as in the Nile Basin of Egypt. In Gulf countries, where irrigation water is more limited, cereal production might be eliminated completely in favor of more efficient high-value crops.

Arab countries will need to import much of their cereal, even in cases when they produce some domestically. There is a complex balance of advantages and sacrifices involved in either importing less cereal, or having more agricultural export earnings with which to import. The tradeoffs - which are different in each country-must be carefully evaluated when considering water policy that shapes production choices.

\section{Investing in rainfed agriculture}

Despite predominately dry climates, many Arab countries depend mainly on rainfed agriculture. In Algeria, Iraq, Jordan, Lebanon, Libya, Mauritania, Morocco, Sudan, Syria, Tunisia, and Yemen, rainfed agriculture is practiced on more than half of all arable land (AOAD 2007). In the Maghreb, Sudan, and Yemen, at least $80 \%$ of cereal production is rainfed. In the Mashreq, half to two-thirds of cereal production is rainfed (FAO 2008b).

Rainfed agriculture in Arab countries is in danger due to climate change. Climate change models indicate that average yearly rainfall could decrease by $10 \%$ in the next 50 years (World Bank 2008f). Droughts and heat waves will become more frequent as weather cycles speed up. As a result, rainfed yields will fluctuate increasingly over time, and average yields will decrease by $20 \%$ in Arab countries overall and almost $40 \%$ in Algeria and Morocco (World Bank 2007a). It is usually the most marginalized farmers and herders who depend most on rainfed agriculture, particularly in the drier areas. These groups will be further impoverished by climate change.

Helping rainfed farmers adapt to climate change requires investment in new technologies. Research on conventionally bred and genetically modified drought-resistant crops is essential for keeping rainfed agriculture economically viable 
(El Obeidy 2006). Conservation tillage has the potential to increase and stabilize yields in drought-prone areas (World Bank 2008e). Trials on rainfed wheat in Morocco have shown higher and more stable yields under conservation tillage, compared to conventional tillage (Mrabet 2002, 2008).

\section{Increasing productivity through research and development}

Arab countries can increase public investment in agricultural research and development. They currently invest approximately $\$ 1.4$ billion annually (Pardey et al. 2006), or $0.66 \%$ of agricultural GDP (Alston et al. 2000). ${ }^{17}$ This is slightly higher than the developing-country average of $0.53 \%$, but far below the recommended level of $2 \%$ of agricultural GDP (Gana et al. 2008), or the developedcountries average of $2.36 \%$ (Alston et al. 2000). Besides the atypical Bahrain, which invests $18 \%$ of its small agricultural GDP in research and development (R\&D), regional leaders are Libya, Jordan, and Morocco (Table 3). It is not only developed countries that invest highly in agricultural R\&D; Brazil invests $1.7 \%$ of agricultural GDP, $1.4 \%$ of which is invested through government agencies (FAO 2008b). Arab countries increased spending on agricultural R\&D by only $0.05 \%$ of agricultural GDP from 1981 to 2000, whereas developed countries increased their spending by $0.95 \%$ (World Bank 2008e). ${ }^{18}$

Arab countries need to enhance incentives for agricultural researchers. The number of agricultural researchers is relatively high, but they are under-funded and ill-equipped. In 1999, there were 14 full-time agricultural researchers per 100,000 rural residents (Table 3). Leaders in this respect are atypical Bahrain, with 457 researchers per 100,000 rural residents, Libya, with 83 , and Lebanon, with $66 .{ }^{19}$ This compares well with agriculturally developed countries such as Argentina, Brazil, and Mexico (Table 3). However, funding per researcher in Arab countries is much lower, and other resources such as information technology infrastructure and support staff are often limited (Gana et al. 2008; Casas et al. 1999). In addition, academic and teaching institutions generally offer better incentives than agricultural research institutes, and are better able to attract $\mathrm{PhD}$ holders.

Arab countries can develop innovative strategies that encourage private-sector investment in agricultural R\&D. Since agricultural research produces mainly public goods, it is difficult to stimulate private investment. Nevertheless, the

\footnotetext{
$\overline{17}$ Around $0.5 \%$ goes to national laboratories, the rest to other public sector research institutions.

${ }^{18}$ There are signs of improvement. Qatar, Tunisia, and UAE have recently been promoting public sector research and development (Gana et al. 2008).

${ }^{19}$ Bahrain's relatively small rural population inflates this figure.
}

investment climate cane be strengthened in several ways, especially through stronger intellectual property rights for improved varieties and other innovations. In Latin America, competitive funding for $R \& D$ has become common. Private firms are allowed to compete for public funds, which they can use to conduct research with private co-financing. Another method is to offer rewards for certain innovations, such as drought-resistant wheat varieties, that are developed by the private sector. Yet another is to encourage innovation by letting farmers apply for grants to implement new technologies. This type of grassroots, farmer-led R\&D has spurred technology dissemination and increased incomes in several countries, including Albania (World Bank 2008i). Ultimately, a partnership between public, private, and farmer-led research will be required to enhance $R \& D$ in Arab countries (World Bank 2008e).

Lastly, countries can promote a multilateral, common research agenda. The League of Arab States (LAS) and the United Nations Development Program recommend a regional R\&D fund with a committed long-term budget (LAS-UNDP 2008). The inability to capture returns to research from beneficial spillovers is a major consequence of underinvestment at the national level (Alston 2002). Because many Arab countries share the same agricultural goals (primarily food security) and challenges (such as water scarcity and climate change), a common multi-nation research agenda could increase the number of beneficiaries. The International Center for Agricultural Research in Dry Areas (ICARDA) has a mandate that covers most Arab countries. The Arab Center for the Studies of Arid Zones and Dry Lands (ACSAD), established by LAS in 1968, has a mandate similar to ICARDA and covers all Arab countries. An independent Arab agriculture fund could work with ICARDA, ACSAD, national research centers, and other organizations to achieve shared objectives.

\section{Dissemination of knowledge}

Arab countries need to couple $R \& D$ investments with better extension. Agricultural extension in Arab countries is poor. In the poorest countries-Somalia, Sudan, and Yemen - it is virtually non-existent. A successful extension program must reach large and small farmers alike. Large farmers have the greatest productive potential per farmer, and the ability to invest in relatively expensive new technologies. Smallholders produce less food per hectare and per farmer, but make up a large proportion of the target population; extension's biggest failure has been not providing them with basic information (Gana et al. 2008). Smallholders often struggle to compete because they lack basic technical and marketing information. They require extension support to produce and market crops, and generate economic opportunities through value addition and other means. 
Table 3 Agriculture research and funding in national agricultural research institutions
Casas et al. (1999); IFPRI 2008a

${ }^{a}$ A potential researcher-year is the equivalent of one year's research. This unit is used because many researchers also do teaching, extension and consulting, in effect making them part-time researchers

- data not available

\begin{tabular}{|c|c|c|c|c|}
\hline Country & $\begin{array}{l}\text { Potential } \\
\text { researcher-years (PRYs) }\end{array}$ & $\begin{array}{l}\text { Funding } \\
\text { (millions of } 2000 \text { US\$) }\end{array}$ & $\begin{array}{l}\mathrm{PRYs} / 100,000 \\
\text { rural residents }\end{array}$ & $\begin{array}{l}\text { Funding as } \\
\% \text { of } \mathrm{AgGDP}\end{array}$ \\
\hline Algeria & 575 & 14 & 8 & 0.4 \\
\hline Bahrain & 32 & 3 & 457 & 17.9 \\
\hline Egypt & 6710 & 68 & 27 & 0.5 \\
\hline Iraq & 770 & - & 30 & - \\
\hline Jordan & 198 & 6 & 35 & 1.2 \\
\hline Lebanon & 83 & 4 & 66 & 0.4 \\
\hline Libya & 261 & 13 & 83 & 1.6 \\
\hline Morocco & 606 & 40 & 6 & 0.9 \\
\hline Sudan & 595 & 3 & 3 & 0.1 \\
\hline Syria & 1058 & 15 & 22 & 0.4 \\
\hline Tunisia & 368 & 15 & 16 & 0.6 \\
\hline UAE & 73 & - & 46 & - \\
\hline Yemen & 245 & 6 & 3 & 0.8 \\
\hline Arab world & 11,574 & 187 & 14 & 0.5 \\
\hline Brazil & 3943 & 924 & 11 & 1.4 \\
\hline Argentina & 1858 & 270 & 45 & 1.0 \\
\hline Mexico & 3097 & 357 & 12 & 1.6 \\
\hline
\end{tabular}

Household assets, land, physical capital, education, and health, are crucial factors in the ability of farmers to secure rural livelihoods and to participate and compete in agricultural markets (World Bank 2008e). Enhancing access to these assets is critical to improving purchasing power and will require significant public investment. A range of options could be used: developing rural infrastructure, improving product markets and access to financial services, strengthening producer organizations, and arranging payments for environmental services.

\section{Reducing exposure to market volatility}

Even if Arab countries can successfully address demand and productivity issues, they will remain net importers of cereals, and will therefore be exposed to the risks of thin markets and high prices. Reducing exposure to cereal-import volatility is the third pillar of the food-security strategy. A number of risk management strategies are available, each with advantages and disadvantages. Each country faces a different mix of quantity and price risk, depending on domestic production potential and natural resource endowments. Each country therefore needs its own tailor-made risk management strategy.

\section{Ensuring stable, affordable, cereal supplies}

A comprehensive review of national cereal procurement methods may reveal simple ways to generate substantial savings. For example, procurement legislation and methods may be inflexible, outdated, or costly. Yemen, for instance, does not consider price or use analytical measures to determine quantity when issuing tenders, instead simply scaling up from previous years (World Bank 1995). Modern procurement systems include electronic tendering, bidding, credit, and transaction-risk mitigation.

Legislative and organizational changes in procurement rules can create immediate and substantial benefits. Arab countries are the world's single largest group of importers. By relaxing national policies prohibiting multinational procurement, they could generate economies of scale and reduce risk. Another reason they do not always receive the best prices and definitive quantities is that they do not use formal risk markets to insure transactions as much as OECD countries, China, India, and other emerging economies. Large transactions present substantial risk, and in a world of limited supply and competitive procurement, Arab countries are at a considerable disadvantage compared to countries that hedge risk. It is possible to overcome this by partnering with large, experienced multinational companies, or by using financial markets to insure transactions (World Bank 2008g).

Poor logistics are another problem. Supply chain logistics are particularly important for reducing costs and improving distribution. Ultimately, this gives consumers more food at lower prices. The GCC countries place well in the World Bank's Logistics Performance Index (Table 4), but poorly compared to other high-income countries. A possible explanation is that because oil exports are so dominant, there has been little pressure from the private sector for trade and transport reform. There is great variation in logistics performance in the Maghreb. Algeria is one of the bottom 10 
Table 4 Logistics performance index: world rankings

\begin{tabular}{llll}
\hline Country & World rank (of 150) & Country & World rank (of 150) \\
\hline UAE & 20 & Mauritania & 67 \\
Bahrain & 36 & Morocco & 94 \\
Saudi Arabia & 41 & Egypt & 97 \\
Kuwait & 44 & Lebanon & 98 \\
Qatar & 46 & Yemen & 112 \\
Oman & 48 & Somalia & 127 \\
Jordan & 52 & Syria & 135 \\
Tunisia & 60 & Algeria & 140 \\
Sudan & 61 & Djibouti & 145 \\
\hline
\end{tabular}

World Bank (2007b)

countries worldwide, whereas Mauritania is in the top half and is ranked sixth among low-income countries. Despite close ties with the EU, Morocco performs far more poorly than Tunisia. Both countries implemented exemplary customs and port reforms, but Tunisia was quicker to improve domestic logistics like trucking and warehousing, and also established an electronic data exchange to simplify customs clearance (World Bank 2007b).

Improved monitoring of world and regional cereal supply and demand will help foresee price shocks, allowing countries to adjust imports accordingly. Although it was impossible to imagine the full magnitude of the 2008 foodprice shocks, some of the causal factors would have been picked up by appropriate monitoring systems. Production and stock projections for the major wheat-producing countries are readily available. For instance, the United States Department of Agriculture publishes monthly projections of wheat production, stocks, and prices. Arab policymakers would benefit from the introduction of systems to collect and assimilate real-time information.

Monitoring domestic supply and demand is challenging because rural people are widely dispersed. By the time it is known that local stocks or production are too low, it could be too late to avert a crisis. The League of Arab States proposes a regional food security monitoring and early warning system that will help determine the quantity and location of assistance needed in response to a food shortage (LAS-UNDP 2008). Such a system could collaborate with global institutions that already monitor food supply. ${ }^{20}$ The creation of weather stations will help predict where shortages may occur, and what quantities of cereal will be needed to stabilize prices (World Bank 2008c, h). Local information can then be aggregated to estimate the quantity of imports needed, and identify areas where it will be most needed.

\footnotetext{
${ }^{20}$ The United States Agency for International Development (USAID) Famine Early Warning System, FAO, and WFP collaborate with local institutions worldwide to monitor potential food shortages.
}

\section{Stockpiling strategies}

Countries need to tailor their stockpiling strategies to their specific needs. Food stocks serve multiple purposes: as rapid emergency food aid in times of crisis, as working stocks for regular distribution, and as buffer stocks to stabilize domestic prices (Dorosh 2008). ${ }^{21}$ Each country must assess their needs, based on national consumption, variability of domestic production, storage costs, size of the country relative to the international market, risks of production shortfalls and high prices, and thinness of international markets. For example, Morocco and Syria would need to gauge domestic production based on rainfall at critical times during the growing season, and adjust their stockpiles accordingly. Since production varies by region within these countries, they would also need to transport stocks internally. In contrast, UAE and Bahrain know the quantity they will have to import $(100 \%)$ without considering domestic production. Their stockpiling strategy would focus on world production and on buying and stocking when quantities are high and prices are low. Since these countries are small, they could conceivably hold their stocks at a central location. Alternatively, they could hold stocks in a neighboring country, like Saudi Arabia, with better infrastructure.

Countries can employ financial risk-hedging instruments as a complement to physical stockpiling. Financial instruments can be used to create virtual stockpiles, ensuring cereals at a certain price without many of the costs associated with physical stockpiles. These methods avoid the high cost of physical stockpiles of perishable materials. ${ }^{22}$ Financial instruments also improve budget planning by allowing importing countries to lock in prices ahead of time. The two primary financial instruments used to establish virtual stockpiles are futures contracts and options. $^{23}$ Some importers continue to use conventional contracts with established suppliers, while using futures and options as an added price-security measure.

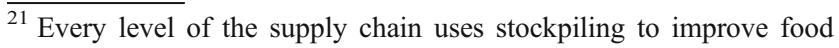
security. Farmers - whether they are net consumers or net buyersstockpile if they think prices will rise. Urban consumers stockpile in times of expected scarcity. Large corporations and governments stockpile to take advantage of high prices or depress prices on domestic markets (World Bank 2008h).

${ }^{22}$ Deterioration, handling, transport, rotation (constant procurement and off-take), and opportunity cost of capital all pose economic barriers to stockpiling. Bigger stocks lead to bigger distributions programs and a larger fiscal deficit (Dorosh 2008).

${ }^{23}$ Options on a terminal market offer more flexibility than futures; they insure the buyer against higher prices, but if the material is not required, there is no obligation to take it. A futures contract on a wellregulated terminal market can act as an insurance policy.
} 


\section{Alternative risk management strategies}

Arab investors are increasingly buying or leasing land in poor but land-abundant countries to secure their food supply. This strategy is often described as a win-win. The investor country acquires land and guaranteed access to the food produced on it, while reaping high financial returns to its investment. The recipient country gets an infusion of capital into agriculture, leading to economic development. For this to truly be a win-win arrangement, however, it is imperative that the investor country is protected from expropriation or nationalization. It is also imperative that the recipient country's citizens are protected from labor abuses and losses of their own food security.

Countries can also invest in the infrastructure used to produce, store, and transport food abroad. This could be permanent infrastructure, such as ports, silos, and roads; mobile infrastructure, such as boats, trucks, and inputs such as fertilizer; or intellectual infrastructure, such as patents to seed varieties and other technologies. Buying land may be unnecessary if an investor can supply and control the infrastructure and technology necessary to produce, transport, and store the food. The recipient would still benefit from higher productivity of land and labor. The investor would have its capital less tied up, and both parties would avoid the political risks associated with land purchase. The Gulf countries would benefit from this strategy, because they would create supply-chain synergies if they both produced oil and controlled the primary production factors dependent on petroleum. If these assets are properly diversified, they also minimize the problems associated with weather and political risk. Bonded warehouses could be constructed in Arab countries, allowing the physical stores tied to international commodity markets to reside inside the region. This would reduce apprehension about purchasing hedges tied to physical wheat located at distant terminal markets and would encourage more trading of the commodity.

Open Access This article is distributed under the terms of the Creative Commons Attribution Noncommercial License which permits any noncommercial use, distribution, and reproduction in any medium, provided the original author(s) and source are credited.

\section{References}

Alston, J. M. (2002). Spillovers. Australian Journal of Agricultural and Resource Economics, 46(3), 315-346.

Alston, J. M., Chan-Kang, C., Marra, M. C., Pardey, P. G., \& Wyatt, T. J. (2000). A meta-analysis of rates of return to agricultural R\&D: Ex Pede Herculem? Washington: International Food Policy Research Institute.

AOAD (Arab Organization for Agricultural Development). (2007). Arab agricultural statistical yearbook. Khartoum: Arab Organization for Agricultural Development.
Beltrán, J. M., Koo-Oshima, S., \& Steduto, P. (2004). Desalination of saline waters. In J. Beltran \& S. Koo-Oshima (Eds.), Water desalination for agriculture. Proceedings of the FAO Expert Consultation on Water Desalinisation for Agricultural Applications, 26-27 April 2004, Rome, Italy. Rome: FAO.

Carter, C., Rausser, G., \& Smith, A. (2008). Causes of the food price boom. Giannini symposium on the causes and consequences of the global food crisis, 10 October 2008, Berkeley, California, USA.

Casas, J., Solh, M. B., \& Hafez, H. (1999). The national research systems in West Asia and North Africa region. Aleppo: International Center for Agricultural Research in the Dry Areas.

Chaibi, M. T. (2000). An overview of desalination for domestic and agriculture needs in remote arid areas. Desalination, 127, 119-133.

Cline, W. R. (2007). Global warming and agriculture: Impact estimates by country. Washington: Peterson Institute.

Dorosh, P. (2008). Public foodgrain stocks and price stabilization in South Asia: Historical experience and policy options. Washington: World Bank.

El Obeidy, A. A. (2006). Introducing new crops with high water-use efficiency in the Middle East and North Africa. In C. Lee \& T. Schaff (Eds.), The future of drylands. The Netherlands: Springer.

Evans, L. T. (1998). Feeding the ten billion: Plants and population growth. New York: Cambridge University Press.

Fabiosa, J. F., Beghin, J. C., Dong, F., Elobeid, A., Tokgoz. S., \& Yu, T.-H. (2008). Land allocation effects of the global ethanol surge: Predictions from the international FAPRI model. Ames: Iowa State University. www.econ.iastate.edu/research/webpapers/pa per_12877_08005.pdf. Accessed 15 February 2010.

FAO (Food and Agriculture Organization). (2008a). Food outlook: Global market analysis. Rome: FAO.

FAO (Food and Agriculture Organization) (2008b). FAOSTAT. Online database. Rome: FAO. http://faostat.fao.org/. Accessed 15 February 2010.

FAO (Food and Agriculture Organization) (2008c). The rise in crude oil prices stimulates ethanol-related demand for agricultural commodities. Rome: FAO. http://www.fao.org/es/esc/en/15/106/ highlight_107.html. Accessed 15 February 2010.

FAO (Food and Agriculture Organization). (2008d). Food outlook. Rome: FAO.

FAO (Food and Agriculture Organization). (2008e). The state of food and agriculture. Biofuels: Prospects, risks, and opportunities. Rome: FAO.

FAO (Food and Agriculture Organization). (2008f). State of food insecurity. Rome: FAO.

Frankel, J. (2008). An explanation of soaring commodity prices. Vox EU, 25 March 2008.

Gana, A., Latiri, K., Suleri, A., \& Ben Zid, R. (2008). Central and West Asia and North Africa summary for decision makers. International Assessment of Agricultural Knowledge Science and Technology for Development (IAASTD). www.agassessment.org/docs/Global_ SDM_060608_English.pdf. Accessed 25 November 2009.

Gardner, B., \& Sumner, D. A. (2007). US agricultural policy reform in 2007 and beyond. In Agricultural policy for the 2007 farm bill and beyond. Washington: American Enterprise Institute.

IFAD (International Fund for Agricultural Development) and FAO (Food and Agriculture Organization). (2007). The status of rural poverty in the NENA. Rome: IFAD.

IFPRI (International Food Policy Research Institute). (2008a). Agricultural Science and Technology Indicators Database. Washington DC: IFPRI. Available at http://www.asti.cgiar.org.

IMF (International Monetary Fund) (2008). World economic and financial survey. Online database. www.imf.org/external/pubs/ft/ weo/2008/02/weodata/index.aspx. Accessed 25 November 2009.

IRIN (Integrated Regional Information Networks) (2005). Yemen: food incentives for girl education. IRIN News, 11 September 2005. www.irinnews.org/report.aspx?reportid $=25459$. Accessed 25 November 2009. 
LAS (League of Arab States) and UNDP (United Nations Development Program). (2008). Food security, poverty, and agriculture in Arab countries: Facts, challenges, and policy considerations. New York: UNDP Regional Bureau for Arab States.

Magnan, N., Lybbert, T. J., McCalla, A. F., \& Lampietti, J. A. (2009). Modeling the limitations and implicit costs of cereal selfsufficiency with minimal data: The case of Morocco. Working paper. Washington: World Bank.

Medina, J. A. (2004). Feasibility of water desalinzation for agriculture. In J. Beltran \& S. Koo-Oshima (Eds.), Water desaliniation for agriculture. Proceedings of the FAO Expert Consultation on Water Desalinisation for Agricultural Applications. 26-27 April 2004, Rome, Italy. Rome: FAO.

Mrabet, R. (2002). Wheat yield and water use efficiency under contrasting residue and tillage systems in a semiarid area of Morocco. Experimental Agriculture, 38, 237-248.

Mrabet, R. (2008). No-tillage systems for sustainable dryland agriculture in Morocco. Rabat: Institut National de la Recherche Agricole. www.inra.org.ma/ist/publications/ouvrages/notillsyst. pdf. Accessed 15 February 2010.

OECD (Organization for Economic Cooperation and Development) and FAO (Food and Agriculture Organization) (2008). The OECD-FAO agricultural outlook, 2008-2017. Online database. www.oecd.org/ pages $/ 0,3355$,en_36774715_36775671_1_1_1_1_1,00.html. Accessed 15 February 2010.

Pardey, P. G., Beintema, N., Dehmer, S., \& Wood, S. (2006). Agricultural research: A growing global divide? Washington: International Food Policy Research Institute.

Rosenzweig, C., \& Parry, M. L. (1996). Potential impacts of climate change on world food supply: A summary of a recent international study. In S. Ramphal \& S. Sinding (Eds.), Population growth and environmental issues. Westport: Greenwood Publishing Group.

Ruttan, V. W. (2002). Productivity growth in world agriculture: sources and constraints. The Journal of Economic Perspectives, 16(4), 161-184.

USDA (United States Department of Agriculture) (2008a). Wheat yearbook. Online database. http://www.ers.usda.gov/Data/Wheat/ WheatYearbook.aspx. Accessed 15 February 2010.

USDA (United States Department of Agriculture). (2008b). Agricultural projections to 2017. Washington: USDA.

Veza, J. M. (2004). Water deslinization and wastewater resuse for agriculture in Spain. In J. Beltran \& S. Koo-Oshima (Eds.), Water desaliniation for agriculture. Proceedings of the FAO Expert Consultation on Water Desalinisation for Agricultural Applications. 26-27 April 2004, Rome, Italy. Rome: FAO.

World Bank. (1995). The wheat subsidy in Yemen. Washington: World Bank.

World Bank. (2006). Sustaining gains in poverty reduction and human development in the Middle East and North Africa. Washington: World Bank.

World Bank. (2007a). Making the most of scarcity: Accountability for better water management in the Middle East and North Africa. Washington: World Bank.

World Bank. (2007b). Connecting to compete: Trade logistics in the global economy. Washington: World Bank.

World Bank. (2008a). Framework document, global food crisis response program. Washington: World Bank.

World Bank (2008b). World Bank online database. Washington: World Bank. www.worldbank.org/data. Accessed 25 November 2009.

World Bank. (2008c). Global financial crisis: responding today, securing tomorrow. Background paper prepared for the G20 summit on financial markets and the world economy. Washington: World Bank.

World Bank. (2008d). MENA poverty and social indicators in MENA. Washington: World Bank.

World Bank. (2008e). World development report 2008: Agriculture for development. Washington: World Bank.
World Bank. (2008f). Changements climatiques et impacts sur l'agriculture au Maroc. Washington: World Bank.

World Bank. (2008g). A first assessment of food security program options available to GCC countries. Washington: World Bank.

World Bank. (2008h). Risk management and the global food crisis. Washington: World Bank.

World Bank. (2008i). Implementation completion and success report on a credit to the Republic of Albania for an agriculture service project. Washington: World Bank.

World Bank. (2008j). Energy efficiency summary. Background paper. Washington: World Bank.

World Bank. (2008k). Economic growth, inequality and poverty: social mobility in Egypt between 2005 and 2008. Washington: World Bank.

World Bank. (2009). Global economic prospects 2009. Washington: World Bank.

WFP (World Food Program). (2008). Rapid assessment on the effects of soaring food prices on the poor segments of the Yemeni population. Draft presentation. Rome: World Food Program.

Yemtsov, R. (2008). The food crisis: Global perspectives and impact on MENA, fiscal and poverty impact. Washington: World Bank.

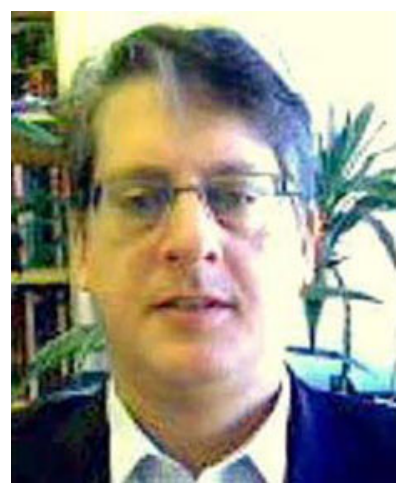

Julian Lampietti coordinates the Agriculture and Rural Development Program in the Middle East and North Africa Region of the World Bank. His current responsibilities include strategy and business development as well as program management. The focus of his current work program is on food security in Arab countries, climate change adaptation in agriculture, food supply chains, and public-private partnerships in marketing. Julian has a B.S. in Agriculture from Rutgers University, an M.S. in Resource Economics from Duke University, and a Ph.D. in Public Policy from the University of North Carolina at Chapel Hill.

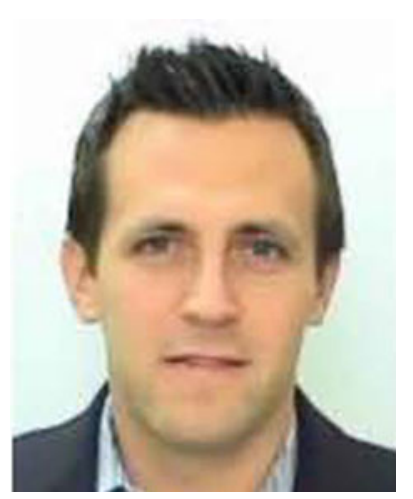

Sean Michaels is an ExtendedTerm Consultant at the World Bank, specializing in food security issues. Mr. Michaels joined the World Bank after several years as a Senior Analyst and Project Manager for the Avascent Group, a leading management consulting firm primarily serving Fortune 100 companies. Mr. Michaels also worked for 2 years as an Advisor to the U.S. Executive Director at the European Bank for Reconstruction and Development (EBRD), where he conducted financial, economic, and political research and analysis on the EBRD's projects and country strategies. Mr. Michaels holds a B.A. in Government with a minor in Economics from the 
College of William and Mary, and a Masters in International Relations with a specialization in International Finance from the Johns Hopkins School of Advanced International Studies (SAIS).

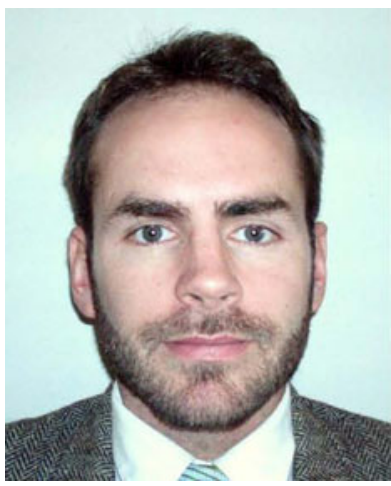

Nicholas Magnan joined IFPRI in 2010 as part of the CGIAR Challenge Program on Climate Change, Agriculture and Food Security (CCAFS). His previous and current research spans the areas of technology adoption, climate change adaptation, sustainable agriculture and agroforestry, drought and pest risk, imperfect markets and property rights, and food security. He received his Ph.D. in Agricultural and Resource Economics from the University of California, Davis in 2010. While completing his degree he concurrently worked on food security issues in the Middle East and North Africa region for the World Bank.

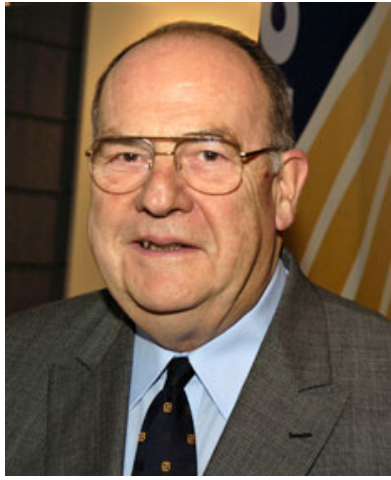

Alex F. McCalla Professor of Agricultural and Resource Economics, Emeritus, and Professor of Management, Emeritus. Davis.

University of California-

Alex McCalla spent his academic career at the University of California-Davis where he taught for 28 years and served as Dean of the College of Agricultural and Environmental Sciences (1970-75) and Founding Dean, Graduate School of Management (1979-1981). When he retired from UCD he worked for the World Bank as Director of Rural Development (1994-1999).

Dr. McCalla is best known for his research in international trade. $\mathrm{He}$ has been honored by the AAEA, the WAEA and CAES as a Fellow or Distinguished Scholar. He was a founding member and Chair of the International Agricultural Trade Research Consortium (IATRC). He served as the Chair of the Technical Advisory Committee (TAC) of the Consultative Group on International Agricultural Research (CGIAR) from 1988 to 1994.

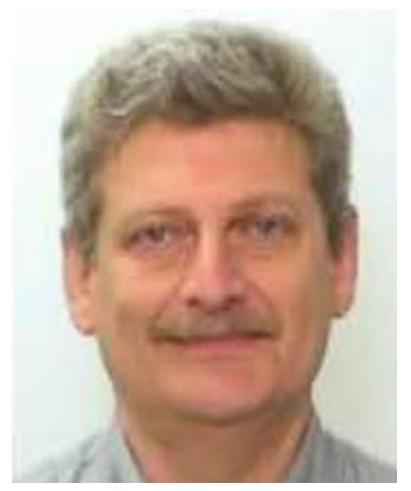

Maurice Saade a national of Syria, is currently a Senior Agriculture Economist at the World Bank's Middle East and North Africa region. He holds a BSc in agriculture and an MSc in crop protection from the American University of Beirut, Lebanon; an MSc in agricultural economics and business from the University of Guelph, Canada; and a $\mathrm{PhD}$ in agricultural economics from Michigan State University, USA.

Mr. Saade started his career in 1989 as Agricultural Economist with the International Center for Agricultural Research in the Dry Areas (ICARDA) first in Aleppo, Syria, and later in Tunis, Tunisia. In 1994, he was appointed Senior Program Officer at the International Development Research Centre (IDRC-Canada), based at IDRC's regional office in Cairo. Starting in 1998, he spent 11 years with FAO as Policy Officer at the Regional Office for the Near East in Cairo, before joining the World Bank in 2009.

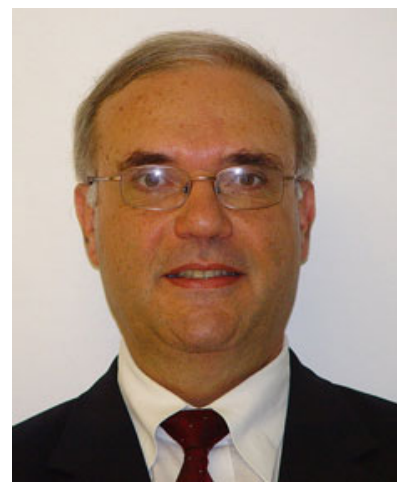

Dr. Nadim Khouri a national of Lebanon, is Director of Near East, North Africa, the Central and Eastern European and Newly Independent States for the International Fund for Agricultural Development (IFAD).

Prior to joining IFAD, Dr Khouri worked for 20 years at the World Bank in agricultural operations. He also held research and technical specialist positions at the American University of Beirut, the University of Massachusetts in Amherst, and Dar al-Hadassah Consulting.

Dr Khouri has a Ph. D in Soil Sciences from the University of Massachusetts, USA; an MSc. in Agricultural Development from the University of London, and an MSc. and BSc. in agronomic sciences from the American University in Beirut 